This is an Accepted Manuscript of an article published by Taylor \& Francis in Journal of Eastern African

Studies on 05 Oct 2019, available online: http://www.tandfonline.com/10.1080/17531055.2019.1674050

Accepted version downloaded at http://eprints.soas.ac.uk/31663/

Dynamics of State-society relations in Ethiopia: Paradoxes of Community

Empowerment and Participation in Irrigation Management

\author{
Daniel Mulugeta \\ Department of Politics and International Studies \\ SOAS, University of London10 Thornhaugh Street, London WC1H 0XG \\ dg30@soas.ac.uk
}

\begin{abstract}
This article examines processes by which development project implementations afford the state the appearance of being a separate structure. By exploring the implementation of an important state development project in Northwestern Ethiopia, the Koga Irrigation and Watershed Management (KIWM) scheme, it shows why and how the project plan does not correspond to the real life of the scheme. The article unpacks assumptions that policymakers and development practitioners make about the a priori existence of a community and state distinction, and the ways in which they arrange them as functionally differentiated entities. It also shows how the project's community-driven participatory approach, wherein local people were involved in managing the scheme, produces the effect of ghettoising practices of abuse as community issues. The article contributes to recent ethnographic studies of state-society relations and contends that these studies could gain important insights by exploring development project implementation practices as an entry point into the study of the processes that give the state the appearance of a material reality.
\end{abstract}

Keywords: State, society, irrigation, participation, Ethiopia.

\title{
Introduction
}

The Weberian assumption that the state as a discrete entity could be studied apart from society has been challenged from anthropological and Foucauldian perspectives which 
document the everyday ways in which the state is deeply embedded in the wider social formation. ${ }^{1}$ In Ethiopian context, several scholars have demonstrated the complex overlap between traditional values and formal institutions, ${ }^{2}$ the interface nature of party-state-peasant relations ${ }^{3}$ and how state-society relations are characterised by a complex interplay of power and authority. ${ }^{4}$ Taking this further, they point towards the theoretical and empirical difficulty of studying the state as an entity distinct from society.

While all of that is certainly true, it is also worth appreciating that the analytical distinction between state and society provides an especially illuminating vantage point to understand the split between the ways in which development practitioners and bureaucrats involved with development project implementations conceptualise the state and the ways in which it works on the ground. ${ }^{5} \mathrm{~A}$ rich research tradition of anthropological research provides an invaluable account of the ways in which various modes of practices constitute the state as a seemingly coherent, dominant and unified entity, separate from and suspended over and above society. ${ }^{6}$ Mitchell ${ }^{7}$ describes this phenomenon of reification as 'structural effects', whereby the 'state' is not an actual structure, but 'the powerful, metaphysical effect of practices that make such structures appear' ${ }^{8}$

I suggest that development - both as a discourse and practice -provides an example of how this process is playing out in Ethiopia. Over the past two decades, the Ethiopian state has increasingly tied its legitimacy to rapid economic growth and poverty reduction efforts. ${ }^{9}$ The government, along with its international development partners, has launched an extraordinary range of development programmes, including the promotion of basic services, irrigation projects, group-based participatory programmes (such as the Productive Safety Net) and cooperative schemes. ${ }^{10}$ In this article, I use the current practices associated with development project implementation as a lens to understand the processes 'through which the uncertain yet powerful distinction between state and society is produced' ${ }^{11}$ 
The development project in question is the Koga Irrigation and Watershed Management (KIWM) project, an important local development scheme in North-western Ethiopia. ${ }^{12}$ This scheme is an interesting case study because throughout the sequential phases in its development (design, training, construction and implementation) local and high-level state functionaries are engaged in activities that differentiate state from society. In examining this project across these stages, the article offers an ethnographic understanding of statecraft, rooted in the 'contingent, contradictory' ${ }^{13}$ and iterative processes and practices ${ }^{14}$ that help to constitute the porous boundaries between state and society. In so doing, it aims to establish three interrelated points. First, state-implemented development and empowerment programmes create the appearance of a distinction between the state and society. However, this distinction is not a product of lower-level politics, but rather reflects the constitutive effects of central state strategies of development and attempts of their enactments by locally situated actors (lower-level state agents). These boundaries in practice are also permeable and constantly in flux.

Second, the technocratic logic of the scheme re/constitutes subject dispositions of the poor and women by articulating gendered and classist discourses pertaining to their capacity to participate in the project. I will show that the scheme works by creating subject positions that reproduce existing power relations and inequalities. This does not however mean that the women and poor people I interviewed are merely passive victims of development practices and lacking in agency. In fact, they do engage with constraints and opportunities actively on a daily basis. This includes recourse to 'twilight institutions' ${ }^{15}$ such as social courts that straddle the supposedly reified realms of state and society. However, the degree of their agency should not be over-stated. Instead of seeing the activities of the poor and women as a form of local resistance against domination by development projects ${ }^{16}$, I demonstrate the ambivalent and contradictory ways in which they at once accommodate and negotiate classist 
and gendered power relations around them. In so doing I reveal the complexities and contradictions of local agency ${ }^{17}$ with respect to processes of state formation and development. $^{18}$

Third, I argue that the boundary, although ambiguous, has very real, material, consequences. In so doing, I point to what James Ferguson calls an 'instrument-effect' of development - side effects unintended by planners such as the expansion of bureaucratic state power and 'ideological effect of depoliticizing both poverty and the state' ${ }^{19}$. My ethnographic descriptions of the effects of the KIWM broadly echo Ferguson's observations about the depoliticising effects ${ }^{20}$ of development practices. However, the process by which the statesociety boundary is produced not only work to depoliticise inequality, prevent meaningful participation and reproduce power hierarchies, but they also ghettoise abuses and resource conflicts by presenting them as community issues rather than those of the state. Given this reality, I argue that decontextualised understanding of state society relations in development planning and implementation can obscure class and gender inequalities.

The article draws on ethnographic fieldwork carried out in the small rural kebele ${ }^{21}$ of Degga, located in west Gojjam Zones of Amhara National Regional State, North-western Ethiopia. Methodologically, it involves the institutional study of practices, documentary analysis of project texts, ${ }^{22}$ and 'thick description' ${ }^{23}$ of project management and everyday interactions at the interface ${ }^{24}$ between state functionaries and local people. Data collection entailed a range of different ethnographic techniques such as in-depth interviews/conversations and direct and participant observations. I met, conversed with and interviewed more than 70 informants, including farmers, government agents and representatives of the local water user association, between September 2014 and January 2015. 
The article first introduces the technocratic logic framing the planning of the scheme. Second it demonstrates how the institutional setting of the scheme reflected the pre-existing top-down hierarchical state bureaucratic set-up, thereby effectively excluding the local population from all decision-making bodies. Third, it analyses how training programmes devised by different government departments are anchored in a problematic divide between tradition and modernity. The fourth and fifth sections examine the effects and material consequences of the appearance of state-society distinction in the lives of local people. The concluding section draws out the article's wider relevance for understanding state-society relations and development project planning.

\section{The KIWM scheme: the logic of the project}

The KIWM scheme is a central agricultural development project which aims to 'contribute towards poverty reduction among smallholders through improvement in food security in the Region [Amhara regional state] in particular and the country as a whole ... [and] to improve agricultural production in the catchment and command areas of the Koga River valley in a sustainable manner'. ${ }^{25}$ Construction began in 2001 and was completed in 2011 after four years of delay. The scheme draws water from the Koga River - one of the 50 tributaries of the upper Blue Nile (locally known as Abay) and irrigates a total land area of 7000 ha across nine kebeles, covering 12 blocks and 11 reservoirs. It enables farmers who are limited to rainfed cropping to produce crops and vegetables during the dry season. The number of beneficiaries at the time of my fieldwork in Degga stood at 942 households. ${ }^{26}$

The scheme was designed and implemented under the aegis of the Ministry of Water, Irrigation and Energy (MoWIE) and was funded by the African Development Bank (AfDB). The scheme's most important feature was the emphasis placed on the participation of farmers and their active involvement at all stages of project implementation, planning, design and 
construction. The logic was threefold. First, both the Ethiopian government and donor agency saw participation as a mechanism to overcome the legacy of public mistrust bequeathed by previous authoritarian projects (e.g. collective farming and villagisation). ${ }^{27}$ The new paradigm was therefore supposed to represent a new form of governance based on the active involvement of the local population, with a view to promoting partnerships between the local population and the state in order to realise the ultimate objectives of agricultural transformation and poverty reduction. The fecundity of linking state and society is reflected in the shift in emphasis from a top-down approach to a 'decentralised and participatory-based project implementation' and 'bottom-up mechanism of accountability' ${ }^{28}$

Secondly, the concern and objective of participation is driven, largely as part of donor conditionality, by the desire to build local capacity, 'a sense of ownership' and 'community self-management capacity, ${ }^{29}$, in order to cede state management and control so that the project would ultimately be sustained solely by community effort. This is supposed to be accomplished by transforming the local population (community), which is presumed to be characterised by horizontal social networks as opposed to the verticality that the state represents, into a WUA that acts to manage its own development and address collective problems. ${ }^{30}$ The scheme in official circles is considered a 'landmark' 31 , 'the first of its kind in Ethiopia' and 'unique' ${ }^{32}$, in that it underscores the dialectical relationship between farmers' empowerment and poverty reduction: empowerment through participation was seen as a means for poverty reduction, and poverty reduction, in turn, was conceived to be a necessary tool with which to encourage participation and collective responsibility for community self-development. ${ }^{33}$

Finally, in Degga, as elsewhere in Ethiopia, participation cannot be understood without reference to the revolutionary democracy ideology of the ruling coalition, the Ethiopian People's Revolutionary Democratic Front's (EPRDF). The EPRDF uses participation as a 
means to mobilise community resources (financial, human and material) and also to implement plans designed by highly placed actors within the party and state apparatus. ${ }^{34}$ In this respect, state/party-organised groups called lematawi buden ${ }^{35}$ (development teams) were actively engaged in project activities, contributing their time and labour for the project construction and maintenance. ${ }^{36}$ For project planners ${ }^{37}$, development team involvement is desirable to mobilise resources such as free labour that would otherwise not be possible to capitalise on. Meanwhile, by emphasising the role of development teams, the party is able to present the scheme as public as opposed to state driven, and hence legitimate. This is a crucial aspect of processes that produce the state as something separate from society.

However, this coevalness of the project's technocratic formulation with the instrumentalist form of participation under EPRDF ideology should be seen as the result of the permeability of the boundary between party and state, and between state and society realms. In practice, the boundaries between state institutions (such as the kebele), and political party are blurred; there is no state empirically distinct from EPRDF party structure in Degga or a state discrete from society. The kebele is a politically and institutionally dynamic site, where people, party politics and institutions often interpenetrate. Decentralised government and bureaucratic structures coexist with 'twilight institutions" ${ }^{38}$ such as social courts and cooperatives. Moreover, the kebele administration in Degga is dominated by EPRDF members called model farmers - a class of largely semi-educated, local notables who maintain relatively significant land holdings and wealth. They are chosen, according to the woreda ${ }^{39}$ administrator, for their 'leadership qualities, progressive and developmental outlook' and for their 'self-made wealth' ${ }^{40}$ These actors are also located within agricultural, micro-finance and water cooperatives. Many of my informants thought model farmers were the first to exploit state resources such as improved varieties of seeds and chemical fertilisers and to take advantage of modern irrigation technologies and wheat procurement schemes. This has 
brought about increased agricultural yields, a higher rate of return from farming, enabling them to accumulate further wealth and consolidate their social prestige and political influence. The formulation of KIWM fails to recognise these overlapping institutional dynamics and the complexity of the power relations on the ground that prefigured the project. It is in this sense that it becomes important to note the slippage between project plans and eventual outcomes concerning participation and empowerment.

Overall, the scheme's logic of participation reveals two facets of boundary-making between state and society. First, in framing the participatory agenda of the project, the MoWIE sought to establish a strong partnership between the state and society. However, the very idea of such a partnership presupposes that the state and the local population are mutually exclusive objects. Although the ministry's aim was to break down the seeming boundary between state and society, it has actually re/produced the boundary and reified the two as independently existing entities.

Second, the whole idea of community participation and community-based organisation is premised on the assumption of the existence of 'community-as-social organisation', ${ }^{41}$ that is, separate from the state. The concept of community (mahbereseb) is abstract, ambiguous and, more to the point, was never before part of the everyday vernacular in Degga. Instead it was previously used to constitute the ideological basis of the Derg regime, i.e. socialism, and was employed at the local level as a label for state-orchestrated meetings and work groups. With the ousting of the Derg, the concept again resurfaced but this time in the context of a participatory development approach. In Degga, it has been widely put to use throughout stateorchestrated awareness campaigns, capacity building programmes and in the process of the formation of the WUA and cooperative groups. Conversely, in everyday life, people use different/various or a plurality terms to refer to a wide range of social relationships. For example, the concept of got (parish) or debere (population settled around one church) are 
used to refer to socio-spatial units, and the terms mahber (religious feasts), idir (burial societies), iqub (informal saving schemes) and wonfel (neighbourhood labour self-help groups) to describe social organisations, whereas the concept of hezeb (population or people) or hezebe-christian (Christian people or community) ${ }^{42}$ have been employed as abstract categories to describe the whole local population. ${ }^{43}$ The concept of population or Christian community is used to describe an abstract entity of social relations with common values, but it does not necessarily describe territorial space.

The key point here is that ideas of belonging to a secular and geographically localised empirical group called community, in which local people act harmoniously and collectively, represented by common public authority, and enjoy the benefits of community-wide relationships of solidarity or possess a representative promoting collective goals to the state, do not exist. Community, in other words, is not an organising social unit. Rather, local social life, as seen above, is dominated by wide and dispersed networks of associational relationships. The point here is not that local residents lack a sense of shared identity. On the contrary. People identify themselves as Amhara, which colloquially means Orthodox Christian. The point here is rather that community is not an 'already existing' empirical group that exists separate from society. Community is a product of an exclusionary (boundarymaking) logic of state practices. This is clearly reflected in my informants' responses to my question asking what community is: 'ye kebele tesatfo' ${ }^{44}$ (participating in kebele activities), 'does it mean people?' ${ }^{45}$, 'It means people', ${ }^{46}$ 'I think it is when we gathered together for kebele meetings', ${ }^{47}$ ' ... when we come to work together in the kebele or irrigation'. ${ }^{48}$ Particularly interesting here is that the concept of 'community' was understood in relation to activities in and around kebele meetings or only in opposition to the state.

The above discussion illustrates how the notion of community is reproduced simply to conform to the national policy agenda of participation and self-management. More 
specifically, it is juxtaposed in relation to the state, as a counter to 'past experience [of] ... large-scale rural development projects in Ethiopia [which] have tended to be driven by government and [whose] acceptance has been low' ${ }^{49}$

\section{Institutional setting}

After the project design, the construction required the establishment of an institutional structure to facilitate local participation. Here, the overall bottom-up approach of project construction and implementation, as noted above, meant that the local population were supposed to be included in institutional decision-making bodies and participate at every stage of the project construction and, in the process, hold government officials to account. However, to do so, in the eyes of the government, they needed to be sufficiently trained and empowered; which gave rise to a top-down panoply of professional and bureaucratic expertise, acting upon a series of hierarchically structured committees, all concerned with downward supervision to the point where it reaches the kebele and then the local population. Within this structure, rather than as partners of the state, the local population were engaged as end-users - exteriors of the state. This is demonstrated in the account below, which describes the organisational structure of those institutions that make up the state apparatus and were involved in the planning and implementation of the scheme.

At the federal level, the controlling agency of the scheme is the MoWIE, located in Addis Ababa. The MoWIE oversees all project activities, devises guidelines, manages project funds, communicates with the donor organisation, the construction contractor and other federal government departments and ensures the project runs conterminous with the larger state policy frameworks. Below the federal level, the scheme was supervised by a regional Project Steering Committee (PSC) located in the regional capital city, Bahir Dar. The PSC members were drawn from the Amhara Bureau of Water Resources, the Amhara Bureau of Agricultural and Rural Development, the Amhara Region Environmental Protection, Land 
Use and Administration Authority, and the Regional Women's Office and the Amhara Region Cooperatives Promotion Bureau. The steering committee prepares and provides training for the local population on a range of issues such as gender equality, agricultural productivity and ethics of work. ${ }^{50}$

At the kebele level, the scheme was coordinated by a project management unit (PMU) committee, whose members include a project manager, who is a politician from the woreda ${ }^{51}$ administration, an agriculturalist, gender coordinator, representative from the woreda Agriculture Bureau, representatives from the nine kebele administrations, a procurement officer, an accountant, and a monitoring and evaluation officer. The project unit members help to mobilise the local population for labour, facilitate and arrange meetings and training sessions, and provide day-to-day construction supervision. They also arrange compensation payment for lost livelihoods at the project site. ${ }^{52}$

Farmers, on the other hand, are placed within the lower ranks of the development ladder and outside the state hierarchical bounds. The formal decision-making structure does not involve either the democratic representation of farmers or any broad-based community participation forum. Instead, the kebele chairman was appointed to represent the local population and ensure that community priorities were included in important decisions. This means that, in contrast to the large number of hierarchically placed professional and bureaucratic state functionaries, the local population approached the scheme with the service of kebele politicians. Consequently, the progressive participatory approach that appears and aims, at least in theory, to create a real possibility of active participation, but turns out in fact, to reify the old top-down paternalist approach which counter-poses state and society as distinct categories, by hierarchically ordering them. One thus notes a 'path-dependent effect', ${ }^{53}$ a condition where the organisation of the everyday operation of the scheme simply reflects the pre-existing bureaucratic hierarchical set-up. In other words, although the project 
was supposed to operate in a bottom-up participatory-based fashion through active farmer participation, the sheer scale and hierarchical nature of the state system obliges the government to rely on a top-down bureaucratic approach. Ultimately, the state has figured as a bureaucratically authoritative, pyramidally structured organisation and as an entity that classifies the local population as exterior 'outsiders' who have to be mobilised, informed and represented by kebele leaders and as far as possible included into the party structures.

\section{The logic of capacity building: the modern state and traditional society}

The benefits of the Koga irrigation scheme were articulated by the scheme's architects not solely in economic terms but also in terms of the social and cultural transformations that it was envisaged would eliminate the underlying social evils of poverty, such as a lack of work discipline. This agenda was numerous training programmes for various sections of the local population - women, the poor and model farmers - between 2002 and 2011. ${ }^{54}$

The project planners ${ }^{55}$ believed that the local cultural and religious belief system posed an obstacle to the proper implementation of the irrigation scheme and prevented the local population from improving their own livelihoods. Most government publications challenge people's religious beliefs, lack of discipline and anti-social and anti-progressive attitudes that are described as regressive attributes that undermine development efforts. A training manual entitled 'Koga irrigation: development and social constraints' described the local 'work culture' as a 'lamentable obstacle to the economic and social progress of farmers'. It further holds that 'it is an exercise in futility to hope for national progress with the current mindset'. ${ }^{56}$ It was claimed that 'proper implementation of community self-management requires fundamental shifts in the norms and attitude of the farmers. The goal is to build social capability for using and sustaining the irrigation on a long-term basis.' The project therefore aims to 'transform ... beliefs and practices which are inimical to economic development and modernity' ${ }^{57}$ 
What does this pedagogical modernisation model of development tell us about the state discourse of boundary work? In designing the training, different government departments positioned the state as a site of rationality and science and the local population as traditional, stagnant and work-shy, and, in doing so, they helped to re/produce a line of difference between state and society. In other words, on one level, characterisations such as 'traditional' assert both the superiority and autonomy of the state; on another level, they construct the local population not only as a separate non-state domain but also as temporally belonging to habits of the past. The result is that poverty and underdevelopment are ascribed more to tradition than to the current structure of inequality (especially in terms of access to resources) that led to growing wealth for the few. Significantly, this threatens the visibility of local class relations and the marginalisation of the poor by projecting them as victims of tradition.

Additionally, the content of the training programmes was framed around the idea that state and society are inhabited by two fundamentally different kinds of people. On the one hand were the small group of people who were considered to be committed to the ideals of progress, rationality, science and technology. On the other hand were the majority of the population who were regarded as irrational, superstitious and traditional. In practice, however, state functionaries can hardly be characterised as 'modern' and 'rational', and they cannot be neatly juxtaposed against the local population. Instead, the identity and interaction between state functionaries and the local population are inextricably shaped and marked by common normative religious and social values. In other words, traditional social and cultural values animate as much the lifeworld of state functionaries as they influence the everyday lives of the local population. For example, during the course of my fieldwork, some civil servants at both the kebele and woreda levels had a high rate of absenteeism on unofficial public holidays. 
On the other hand, most of the farmers were enthusiastic about and keen to take advantage of new agricultural technologies such as chemical fertilisers and hybrid varieties of seeds. The crux of the matter is that shared normative cultural practices interpellate both state functionaries and the local population in their daily lives and hence produce subjects who perform roles that cannot be neatly categorised as either modern or traditional. Therefore, tradition as a distinct domain that belongs to society is a context created by political actors and technocrats which quite fundamentally illustrates the statist practice of boundary-making.

\section{Institutionalisation of the state-society boundary: the WUA}

In addition to providing capacity building training, the MoWIR and AfDB determined that the legitimacy and sustainability of the project required the formation of a farmer-driven participatory institution that would articulate 'community interests' 58 and serve as an intermediary between the local people and the local institutions that constitute the state. ${ }^{59}$

To this effect, in 2011, water cooperatives (WUAs) were established across the nine kebeles served by the irrigation system and federated to form one Koga Irrigation Cooperative ${ }^{60}$ Here, the practice of producing and institutionalising the distinction between state and society finds its expression in a WUA by-law, which was prepared by the Amhara Regional Bureau of Cooperatives Promotion. The first element that the by-law established was distinctive state and non-state realms of authority. This involves division of responsibilities between the local institutions that make up the state apparatus and the local community/WUA. The by-law, for instance, states that a Project Operation Unit (POU), as a branch of government bureaucracy, operates 'the dam and reservoir, main and secondary canals and drains and the associated road network', whereas the WUA is responsible for the 'O\&M [Operations and Maintenance] of the tertiary and quaternary canals and drains and associated access roads and on-farm structures' ${ }^{61}$ Furthermore, the WUA is charged with the optimal allocation and utilisation of the water resource, generating local resources in cash or 
labour for maintenance and operations, preventing erosion, ensuring the interests of the owners and users of the land plots and sanctioning violations of the rules. ${ }^{62}$ Thus, the local population were designated as exteriors to the state and treated as discrete development actors. The WUA, in this sense, represents the institutionalisation of the two schemas, the state and the local community, governed by a by-law which dictates specific rules, regulations and parameters on how the two are supposed to relate to one another.

The second element introduced with the by-law was that the WUA, as a self-managed development actor, was to be run by a committee of seven community representatives who were to be elected as its members. The by-law, however, recommends that the leadership committee is composed of respected village elders, preferably those who can read and write. ${ }^{63}$ The problem here was that the requirement for literacy and social status helped erstwhile dominant semi-educated social and political elites (model farmers) to continue their domination. At the time of my fieldwork, the leaders of the WUA in Degga were the same few elites who occupied multiple positions at various levels of the kebele administration. The chairman of the association was, for instance, the Degga kebele’s Amhara Democratic Party (ADP)/EPRDF head. It is clear then that the formation of the WUA - as a discrete community body separate from the kebele institution - has not affected local power relations. Rather, by distinguishing the elite from ordinary inhabitants, it reproduces and reinforces local stratifications, hierarchies and thereby perpetuates erstwhile power relations. As such, the boundary between the state and the local population, as we shall see later, simply serves as a resource of power and personal enrichment for those local elites on both sides of the dichotomy.

\section{Participation and subject sensibilities}


This section examines how state training programmes induce farmers to identify themselves as 'underdeveloped subjects' ${ }^{64}$ in order to demonstrate the contradictory effects of development and boundary-making practices. It does so by paying close attention to the ways in which training programmes and development discourses intended to encourage participation in fact informed the poor of their inferior position vis-à-vis (semi-)educated members of the local population.

The grassroots' vernacular understanding of the concept of participation has roots in the verb 'to participate', i.e. mesatef, which means to attend events, meetings or public works, etc. Participation, to the local population, therefore, simply implies attending meetings to receive information and listen to the eloquent and witty speeches and technical and forceful words given by state functionaries and public leaders. Many of my informants were surprised when I informed them that the project's official view on participation ${ }^{65}$ entails the idea that participants are in charge of discourses, that they have the right to vote and be elected and that all local inhabitants should have an equal voice in decision-making processes. They would then be confounded by any difference this might make. 'Regardless, it is not our place. A farmer toils with dirt and dust. We are not people of paper and pen’66 said a middle-aged farmer. Similarly, another middle-aged farmer expressed: 'We [ordinary farmers] must accept whatever comes. A donkey and a farmer should consent to take orders. ${ }^{67}$ Another elderly man said, 'Who would listen to a farmer? We are looked down upon by everyone. ${ }^{68}$ It is tempting to interpret these responses as a reflection of the dynamics of the Ethiopian authoritarian political tradition and the culture of obeisance to authority. ${ }^{69}$ Such an approach, however, fails to account for the ongoing complex contemporary practices that re/produce structural positions and the norms governing the participation of the local people in decision making processes. 
Despite the scheme's founding aim of transforming local inhabitants into empowered subjects, norms governing the participation of local people are animated by a constantly re/produced set of discourses and governance practices that constitute social classes and underdeveloped subjects . In particular, development and participation discourses were used by local inhabitants as points of reference against which they constituted not only ideas of state but also 'underdeveloped' subjectivities. State capacity building programmes, as seen in the first section, set the terms by which - and are key mediums through which - subject positions are managed. Many of the people I interacted with expressed that it is impossible to be active participants because, as one middle-aged farmer expressed, 'participation requires the ability to read and write' and he is an 'uneducated peasant' ${ }^{70}$ Here, an awareness of his illiteracy not only tells my informant that he cannot actively participate but also informs his sense of self as an 'uneducated peasant' and certainly positions him as such in the context of wider power relations. When asked to account for their lack of active participation, the majority of my informants drew on state discourses and described themselves using disparaging terms. One man remarked, 'I cannot meaningfully participate because I am illiterate. We were told that working in the association [WUA] requires the ability to read and write. I have nothing useful to contribute to the WUA.' ${ }^{71}$ Many of the ordinary farmers were conscious of and sensitive to the structural and social contexts within which participation is required. One middle-aged farmer told me, 'It was made clear to us during the training programmes the WUA needs educated people as leaders'. He further added, 'I am not useful for them. My role is to learn what mengist ${ }^{72}$ teaches me ... I have no one to blame but myself ${ }^{73}$ Similarly, another middle-aged man said, 'participation is best achieved only when educated people take the responsibility of leadership ... As to the illiterate farmers ... what we learn at meetings [training programmes] is sometimes difficult to comprehend. Only those who read and write can communicate better with mengist ... poor people attend just to make 
up the quorum. ${ }^{74}$ These comments illustrate that in the context of active participation, the training programmes and subsequent elections of WUA leaders privileged literacy and devalued the agency of those who did not read and write.

Despite the purpose behind the training programmes being to empower farmers, they were, as the comments above demonstrate, unwittingly grounded in radical selfconsciousness-raising projects, i.e. telling peasants what they are and do not have instead of how they can be. What farmers see is that they lack access, power and education and thereby any meaningful position in the participatory community management programme. By inculcating and pointing out the state-specified terms within which participation takes place, my informants constructed subordinated subjectivities.

With respect to the local leadership, many of my informants compared their lives with those who were educated, powerful and wealthy, often belittling themselves in the process. They considered themselves as 'lacking in education' ${ }^{75}$ and 'knowledge of mengist' ${ }^{76}$ that defined local elites. In most cases, people's endorsement of WUA representatives relates to the state's emphasis on education and denigration of their agency which informs their sense of self, rather than local leaders' ability to deliver economic and social benefits. In other words, individuals' self-awareness of their situated constraints allows them to visualise and imagine how community participation is expected to work and who is well positioned to fit the expectations. Yet this does not mean that peasants accept all abuse of power and resources. They in fact try to contest or negotiate the abuse of power by semi-literate community representatives and state functionaries through institutions such as social courts.

Indeed, in the view of my informants, the notion of participation, in the context of attending meetings, is significant. Most spoke positively about the information and knowledge they derived from the training programmes. They also embrace the 'modernist' 
hope generated by state discourses. Almost all the illiterate people I spoke to were keen to send their children to school and prevent them from meeting the same fate. But they were also convinced that they cannot do anything about their illiteracy and material constraints. ' $\mathrm{I}$ have received so many great ideas from the project people about how to use irrigation water and start an animal fattening business. But I am poor. I have no resources to put the information I gathered into practice,' explained a middle-aged farmer. ${ }^{77}$ Similarly, another middle-aged man said, 'I have learned so many things ... what and when to plan, soil erosion, water and fertiliser use, etc. But, I don’t have what the rich people have ... land, fertiliser and money. Learning is good for nothing: I still struggle to feed my family. ${ }^{78}$ Another man stated: 'They teach us zemen ametash [modern] methods ... but I have not seen training resulting in any benefit for the poor. They are good for the rich. ${ }^{79}$ In short, knowledge of farming technology and methods which underpin capacity building discourses only served to create 'underdeveloped as a subject and underdevelopment as a form of identity' ${ }^{80}$.

\section{Utilisation and management of the irrigation facility}

By 2011, construction activities had been completed and the farmers began to utilise the system for production in the dry season. In the meantime, management of the canal system was handed over to the WUA. The division between management responsibilities between the local state institutions and the local community/WUA brings into sharp focus the distinction between state and society by defining who and what constitute such domains and by making legible the agencies and individuals who perform roles that are recognised as either state or community. This process has helped to make a boundary between state and society appears as an empirical reality in the eyes of both the state functionaries and the local population. As I will demonstrate below, this 'state effect' ${ }^{81}$ has been practically consequential in that it established an institutionalised relationship between the local institutions that make up the state apparatus and the local population based on the principles 
of community self-management and limited state involvement, thereby exposing women and poor people to asymmetrical gender and class-based community relations that undermined their access to water and other resources. The effort to build community self-empowerment by treating the local population as discrete development actors separate from the state has therefore had the contradictory effect of perpetuating class and gender divisions.

To begin with I explore the local patterns of irrigation water and land use and market constraints in place ever since farmers began to utilise the irrigation system. ${ }^{82}$ In Degga, the lowest, most fertile and best-irrigated parts on the banks of the canals are cultivated by the rich and powerful. If the wealthy did not already own the land near the canals before they were built, they soon acquired it through long-term rent contracts or exchanges of land. The regional law permits land rent-outs by smallholders for up to 10 years for annual crops and for a maximum of 30 years for permanent fruit plants or preferred tree types. ${ }^{83}$ Particularly, during the first few years in which farmers began irrigating their land, market constraints allowed local elites and wealthy urban opportunists to rent land from poor, cash-strapped farmers. In 2011, for instance, with almost all of the farmers producing similar vegetables and crops such as tomatoes and onions and marketing during the same period of time, there was excess supply in the market. This resulted in a sharp fall in price. The tomato surplus especially could not be stored because of a lack of cold storage rooms. Urban-based traders made matters worse by quoting lower prices on tomatoes, forcing farmers to sell at a price as low as 10 ETB (£0.33) per quintal. Widowed women and poor farmers ended up renting out their plots to wealthy farmers and outsiders and becoming household and commercial farm labourers. $^{84}$

Over the following years, cognisant of market constraints, the government established the Amhara Seed Enterprise to contract farmers to grow commercial quantities of onion and wheat seeds at government procurement prices, way above the market value. ${ }^{85}$ At the local 
level, the contracting process was primarily managed through the WUA and development agents (DAs), who are under the influence of local kebele cadres that straddle the line between the state and community. The result was that the work was almost entirely contracted out to wealthier farmers. ${ }^{86}$ Poor farmers are thus forced to rely on fast-yielding vegetables and tomatoes, thereby sharply reducing the demand for chemical fertiliser. However, the vegetable and tomato markets are too variable to secure an income.

This situation is exacerbated by institutional restrictions. As the community, i.e. the WUA, is separate from public institutions, state actors are not able to interfere in the day-to-day monitoring of water distribution and management of disputes. At the same time, local elites (model farmers) dominate the leadership positions in the WUA. In order to keep their vast areas of land under cultivation, wealthy and powerful farmers use a great deal of water, reducing and sometimes denying water allocated to the poor. Community rights to water access are simply overridden by the growing quantity of crops produced commercially for the government by model farmers. As a result, I encountered persistent and extensive local complaints about exclusion from water distribution and the absence of any state help. One farmer explained his experience with his wealthier neighbour:

He blocks the water to my field and diverts it to his own fields. I needed water desperately because tomato and vegetables [that he cultivated] need regular watering. He says that I only need little water because I have small plot ... and sometimes he denies my turn ... It is WUA's responsibility. Mengist cannot help me. ${ }^{87}$

Some have even given up farming during the dry season. One middle-aged farmer, for instance, reflected on his experience as follows:

I have completely quit farming in dry seasons. It is costly ... it needs land preparation, pesticide and regular watering ... You have to fight with the rich to secure your right to 
access water .... It is an association's [WUA] thing, mengist can't help you ... ultimately, either your crops perish for lack of water or the market plummets and you end up selling them at a cheaper price that does not even cover your inputs and labour costs. ${ }^{88}$

Because of the multiple constraints, many household heads, especially women, entered into sharecropping arrangements with wealthier farmers:

It is easier for [widowed] women to enter into sharecropping. Farming is a man’s job. I am not capable of negotiation like a man to acquire fertiliser: I am weak to participate in maintenance work, and my children are very young. Added to that, there is no support [for widows] from the government with respect to water use or fertiliser. Everything is decided by the rich people in the cooperative [WUA]; there is not government involvement at all. ${ }^{89}$

Experiences of abuse also surfaced in local complaints. A middle-aged farmer pointed out his own experience as a case in point:

I have suffered the worst abuse ... I had a problem with a rich man who has a big farm at the head. He used to block water and refuse to give me my turn. I reported it to the association [WUA], but they have done nothing. Then I reported it to a government person at the project office, and he told me it is 'the association's issue; they will deal with it'. Left with no other option, I decided to confront him. He sent his labourers to beat me. I reported it to the militia and the social court and they have done nothing. I then took the case to an elder, and the elder reprimanded his brutality towards me. I don't know if it lasts but, for now, he respects my turn. ${ }^{90}$ 
Notable from this case is how, in the struggle over access to water, the realms of state and society have been restricted by the parameters of institutions and the law and negotiating points have been narrowed down to internal village social relations, with no oversight or intermediation from external state functionaries. The most well-connected individuals rely on power derived from kinship networks in their clash over access to water. Others were ghettoised into a system where no immediate legal or administrative action may be brought against the powerful.

It should be noted here that relations between the local people and social courts are ambiguous and dynamic. Social courts operate in the twilight between state and society, using a combination of formal and customary law. Similarly, elders are part of a complex network of informal alliances both within and outside the kebele administration. This fluid socio-political field of intermediaries provide residents with choices and opportunity in negotiating water rights and exercise their agency. It also, however, means that the elders have to work to consolidate their positions of prominence with the local people by offering services of mediation, while simultaneously maintaining their alliances with powerful and wealthy individuals. Such realities impact on the agency of the poor and women creating opportunities for negotiating in the complexities of local power relations as well as circumscribing their voice.

Returning to local complaints, many people expressed their frustrations related to canal maintenance. Although it is the responsibility of the WUA to mobilise labour, it is usually individual peasants who clear debris from canals. My informants cited that wealthier farmers receive special attention from the WUA while their own demands go unanswered. For instance, a middle-aged farmer said: 
When damage occurs in areas which affect the rich, we all participate in the repair process. The association pays special attention to the demands of the rich. Sometimes they call government people [engineers] to clear the canals using graders. But when I and many other [whose land is located on heads of the watercourse] need help to carry water uphill, no one responds. ${ }^{91}$

Similarly, another young peasant complained:

When we need [technical] help from the government, we should submit an application in writing on a piece of paper to the association. The association treats an application from a rich man and myself differently. They make sure the rich get help from the government. We [whose land is uphill] are still pleading with the WUA for canal clearance. $^{92}$

Here, my informants are referring to the established institutional procedure of requesting technical help from the government where technical assistance can only be requested through the WUA (which is assumed to represent the interests of the local community). However, in practice, as my informants indicated, such requests from poor members are often ignored, leaving them to their own devices.

In almost every case from the informants above and in my interviews with many other farmers, those who expressed their complaints and frustrations found that they were unfairly treated by local elites, not by mengist. As one elderly man said: 'it is our own children [local elites] who make us suffer.' These comments from different informants reveal that boundarymaking practices have locked poor people and women into livelihoods that are not empowering. Ironically, far from benefitting from the irrigation scheme, the peasants might, in fact, become worse off by ceding 20 per cent of their landholding for canal construction. 
To summarise, the participatory aspect of the scheme aimed at community selfmanagement and self-empowerment had the contradictory effect of sustaining class differences partly because of the unrealistic assumption of the existence of community as a harmonious whole that is separate from the state. The assumption that the project can be equitably managed through the WUA has 'depoliticised' local practices of abuse, not because, as Ferguson ${ }^{93}$ argued in the case of Lesotho, of the technical aspects of the project, but rather because it has become ghettoised and incarcerated as a community issue. Ultimately, as we have seen, the fruits of the project have failed to reach the poor.

\section{Conclusion}

This article has examined the complex development practices and processes in the KIWM to substantiate three aspects of state-society dynamics in Ethiopia. First it has shown that the distinction between state and society arises from complex, locally grounded practices of boundary-making and the production of difference. Second, the state-society boundary is in reality unclear, elusive and porous. This was demonstrated through the prism of various domains of project implementation: planning, design, construction, institutionalisation and usage pattern. In all these domains, the multiplicity of actors, their positionalities and overlapping relations points to the dynamism and permeability of the boundary between state and society. Finally, it has shown that the distinction between state and society was nevertheless perceived as a real boundary and has been acted upon.

The thick description of the project also calls to attention the distinction between the rendition of the implementation of the community-based and -driven aspect of the project and its real life. The participatory approach of the scheme was spurred by the impulse to reach out and empower marginalised sections of local communities which should be allowed to have an equal say regarding their own development. However, the strategy of achieving this through 
training had the paradoxical effect of informing the peasants what they are and what they lack for them to meaningfully participate.

Community participation as a project of empowerment, when examined through the prism of an ethnography of state-society relations, is precarious. If we take the experiences, struggles and subjectivities of rural people seriously, then we need also to question the significance of community-based and driven projects as a means to empower rural people and create self-reliant communities. Projects such as KIWM, instead of producing selfempowered communities, further entrench the centrality of the idea of an autonomous state in rural people's imagination and lives and reproduce and reaffirm the line between state and society. This has significant material consequences in terms of farmers' access to water and land resources and technical assistance. My contention is that regardless of whether the state is imagined as being benign or authoritarian, whether it is legitimate or not, or whether it is contested or negotiated, it remains significant in the lives of rural people; that they do not wish it away or seek to reduce the level of its involvement.

Overall the study demonstrated the importance of the state idea and also how the contingent nature of the state-society boundary that characterises rural Ethiopia shapes the working of the state. Such empirically grounded ethnographic research of the state that takes into account both processes and practices of development administration helps to frame our understanding of state-society relations.

\section{Notes}

${ }^{1}$ Abrams, "Notes on the Difficulty of Studying the State”; Mitchell, "Society, Economy, and the State Effect”; Hansen and Stepputat, States of Imagination; Migdal, State in Society.

2 Abbink, “Discomfiture of democracy?”; Lefort, “Powers—Mengist—and Peasants”.

3 Lefort, "Free market economy, 'developmental state”; Vaughan, "Revolutionary Democratic State Building”; Planel, “A view of a bureaucratic developmental state”. 
${ }^{4}$ Vaughan and Tronvoll, The Culture of Power.

${ }^{5}$ Scott, Seeing like a State; Mitchell, “Society, Economy, and the State Effect”.

6 Gupta, "Blurred boundaries"; Mitchell, "Society, Economy, and the State Effect";

Bliesemann de Guevara Introduction: Statebuilding and state formation.

${ }^{7}$ Mitchell, “Society, Economy, and the State Effect”, 89.

${ }^{8}$ This departs from the common understanding of state formation as a top-down expansion of centralised control by the army, bureaucracy and capital. See Bliesemann de Guevara, Introduction: Statebuilding and state formation for a critical discussion of these debates.

${ }^{9}$ de Waal, The real politics of the Horn of Africa.

${ }^{10}$ Fantu, Cramer, and Arkebe, Handbook of the Ethiopian Economy.

${ }^{11}$ Mitchell, "Society, Economy, and the State Effect”, 77.

${ }^{12}$ In a public speech at the Millennium Hall in Addis Ababa during his first anniversary in April 2019, current Prime Minster Abiy Ahmed announced irrigation would be one of top priorities for government spending to deal with the problem of rural unemployment.

${ }^{13}$ Bliesemann de Guevara, Introduction: Statebuilding and state formation.

${ }^{14}$ In this article I use the term practice to draw attention to activities associated with the various aspects of the project implementation process: planning, design, construction, institutionalisation and usage pattern. See, for example, Bourdieu, Outline of a Theory of Practice.

${ }^{15}$ Lund, “Twilight Institutions”.

${ }^{16}$ Escobar, Encountering development; Scott, Weapons of the Weak.

${ }^{17}$ Hall, “Cultural identity”.

${ }^{18}$ Long, Development Sociology.

${ }^{19}$ Ferguson, The Anti-Politics Machine, 256. 
${ }^{20}$ Ferguson (1994) used the concept of 'depoliticisation' to refer to the suspension of politics and the practice of reducing poverty to a technical problem in Lesotho. I use the term depoliticisation to draw attention to the ways development obscures local repressive class and gender structures operating at micro-level and the ways in which it deflects attention away from existing power inequalities within the kebele population.

${ }^{21}$ Kebele is the lowest administrative unit in Ethiopia and typically has a population of between 5,000 and 10,000 people.

${ }^{22}$ The sources of documentary analysis of project texts are government documents such as training manuals, water users association (WUA) documents, project guidelines and field reports by the project consultant Mott MacDonald (MMD) which I have studied during my fieldwork.

${ }^{23}$ Geertz, The Interpretation of Cultures.

${ }^{24}$ Long, Development Sociology.

${ }^{25}$ AfDB, Koga Irrigation and Watershed Management Project, i.

${ }^{26}$ Interview, PMU officer\#13, woreda town, October 2014.

${ }^{27}$ Interview, senior PMU officer\#14, woreda town, October 2014.

${ }^{28}$ Interview, senior Amhara bureau of water resources official\#15, Bahir Dar, October 2014.

${ }^{29}$ MMD Koga Irrigation Project, 2005a, 4.

${ }^{30}$ Ibid., 27.

${ }^{31}$ Interview, senior PMU officer\#14, woreda town, October 2014.

${ }^{32}$ Interview, senior Amhara bureau of water resources official\#15, Bahir Dar, November 2014.

${ }^{33}$ Interview, senior Amhara bureau of water resources official\#15, Bahir Dar, November 2014 
${ }^{34}$ Williamson, "So near and yet so far"; Vaughan and Tronvoll, The Culture of Power; Smit et al,. “The Political Morphology of Drainage”.

${ }^{35}$ Lematawi buden are typically led by cadre farmers who serve as a liaison between the team and the kebele administration, ensure the attendance of members and exact fines on absentees (50 birr in Degga).

${ }^{36}$ The character of the Ethiopian state has been changing rapidly as a result of the ongoing political reforms that were initiated since April 2018. Notwithstanding these transformations, in a recent conversation with some of my informants in Degga I found that party/state structures such as development teams are still operational, and model farmers still largely control both kebele institutions and access to important resources such as agricultural inputs. Although the changes seems to have created party political disillusionment, I found no evidence whatsoever of the disbandment of party and state structures. The only point that can be argued with any degree of confidence is that that reform is less likely to result in substantive class and gender equality at the local level in the near future.

${ }^{37}$ Interview, senior PMU officer\#14, October 2014.

38 Lund, “Twilight Institutions”.

${ }^{39}$ Woreda is an administrative unit similar to district and is found above kebele.

${ }^{40}$ Interview, woreda administrator, November 2014.

${ }^{41}$ Agrawal, “Community-in-conservation”.

42 This is because Degga is $100 \%$ Orthodox Christian kebele.

${ }^{43}$ Field notes, September - December 2014.

${ }^{44}$ Interview, middle-aged farmer\#16, October 2014.

${ }^{45}$ Interview, middle-aged woman\#17, October 2014.

${ }^{46}$ Interview, middle-aged trader-cum-farmer\#18, October 2014.

${ }^{47}$ Interview, young farmer\#19, November 2014. 
${ }^{48}$ Interview, middle-aged farmer\#20, November 2014.

${ }^{49}$ AfDB, Koga Irrigation and Watershed Management Project, 8.

${ }^{50}$ Gebre, Getachew and McCartney, Stakeholder analysis.

${ }^{51}$ Woreda is an administrative unit similar to district and is found above kebele.

${ }^{52}$ Farmers who were completely displaced because of the construction of the reservoir were compensated financially and with land for loss of farm plots, houses, trees, and for the estimated value of the crop produce for three consecutive years. However, those farmers who ceded up to $20 \%$ of their land for canal construction did not receive any compensation. Most of them volunteered to do so in view of the benefits they expected from the project after completion.

${ }^{53}$ Mayrl and Quinn, “Defining the state from within”.

${ }^{54}$ Interview, senior PMU officer\#14, October 2014.

${ }^{55}$ Ibid.

${ }^{56}$ MoWR, Koga irrigation.

${ }^{57}$ Ibid.

${ }^{58}$ Interview, head of the WUA\#24, Degga, November 2014.

${ }^{59}$ Interview, senior PMU officer\#14, November 2014.

${ }^{60}$ There was nothing new or unique about this form of arrangement. On the contrary, it is a typical way of arranging an irrigation management system and is used all over the world. But the formation of the WUA, in the context of this study, is significant insofar as it offers insight into how the boundary between state and society is produced and reaffirmed.

${ }^{61}$ MMD, Koga Irrigation Project, 2005b.

62 Ibid.

${ }^{63}$ Ibid.

${ }^{64}$ Gupta, Postcolonial developments. 
${ }^{65}$ MMD, Koga Irrigation Project, 2005a, 4.

${ }^{66}$ Interview, middle-aged farmer\#25, Degga, October 2014.

${ }^{67}$ Interview, middle-aged farmer\#16, Degga, October 2014.

${ }^{68}$ Interview, elderly man\#26, Degga, October 2014.

${ }^{69}$ Lefort, "Powers-Mengist—and Peasants".

${ }^{70}$ Interview, middle-aged farmer\#27, Degga, October 2014.

${ }^{71}$ Interview, middle-aged farmer\#28, Degga, October 2014.

${ }^{72}$ My informants often referred to the state, government officials, and powerful people as mengist. However, they made distinctions between a corrupt local bureaucracy and an impartial central state. The popular discursive construction of impartial central state is very much associated with paternalistic care and expectations of providence, munificence and reciprocity.

${ }^{73}$ Interview, middle-aged farmer\#25, Degga, October 2014.

${ }^{74}$ Interview, middle-aged farmer\#29, Degga, October 2014.

${ }^{75}$ Interview, elderly man\#30, Degga, October 2014.

${ }^{76}$ Interview, young man\#31, Degga, October 2014.

${ }^{77}$ Interview, middle-aged farmer\#29, Degga, October 2014.

${ }^{78}$ Interview, middle-aged farmer\#25, Degga, October 2014.

${ }^{79}$ Interview, elderly farmer\#30, Degga, October 2014.

${ }^{80}$ Gupta, Postcolonial developments, 11.

${ }^{81}$ Mitchell, "Society, Economy, and the State Effect”.

${ }^{82}$ See also Smit et al,. “The Political Morphology of Drainage” for similar discussion.

83 The Revised Amhara National Regional State. Rural Land Administration and Use. No.252/2017. The previous proclamation (No. 133/2006) permitted land rent out for up to 25 years for any type of production. The shortening of the maximum period for crop production 
to 10 years and the formalisation of rental transactions may protect vulnerable group members who are unable to cultivate their land for a variety of reasons.

${ }^{84}$ Interviews with two DAs (DA\#5 and DA\#8), Degga, November 2014; interview, middleaged woman\#32, November 2014.

${ }^{85}$ Interview, DA\#7, Degga, November 2014.

${ }^{86}$ Ibid.

${ }^{87}$ Interview, middle-aged farmer\#33, Degga, November 2014.

${ }^{88}$ Interview, middle-aged farmer\#29, November 2014.

${ }^{89}$ Interview, widowed woman\#34, November 2014.

${ }^{90}$ Interview, middle-aged farmer\#35, November 2014.

${ }^{91}$ Interview, middle-aged farmer\#20, November 2014.

${ }^{92}$ Interview, young farmer\#19, November 2014.

${ }^{93}$ Ferguson, The Anti-Politics Machine.

\section{Bibliography}

Abbink, J. "Discomfiture of Democracy? The 2005 Election Crisis in Ethiopia and its Aftermath.” African Affairs 105 (2006): 1173-199.Abrams, Philip. "Notes on the Difficulty of Studying the. State.” Journal of Historical Sociology 1 (1), 1988: 57-84.

African Development Bank (AfDB). Koga Irrigation and Watershed Management Project: Appraisal Report. Abidjan, February 2001.

Agrawal, A. Community-in-conservation: tracing the outlines of an enchanting concept. In A new moral economy for India's forests? Discourses of community and participation, edited by R. Jeffery and N. Sundar, 92-108. New Delhi: Sage, 1999.

ANRS (Amhara National Regional State). “The Revised Amhara National Regional State Rural Land Administration and Use Proclamation.” Zikira- Hig of the Council of 
Amhara National Regional State. [2006]2017.

Bliesemann de Guevara, B. Introduction. Statebuilding and state formation. In Statebuilding and State Formation. The Political Sociology of Intervention, edited by $\mathrm{B}$. Bliesemann de Guevara, 1-19. Abingdon, UK: Routledge, 2012.

Bourdieu, P. Outline of a Theory of Practice. Translated by Richard Nice. Cambridge: Cambridge University Press, 1977.

de Waal, A. The real politics of the Horn of Africa: money, war and the business of power, Cambridge; Polity, 2015.

Escobar, A. Encountering development: the making and unmaking of the Third World. Princeton University Press, 1995.

Fana Television “A speech by Abiy Ahmed on his one-year anniversary” [Translated]. Video File. April 2, 2019. https://www.youtube.com/watch?v=Wn3YcmL8FGk

Fantu C., Cramer, C., and Arkebe Q. The Oxford Handbook of the Ethiopian Economy. Oxford, Oxford University Press, 2019.

Ferguson, J. The Anti-Politics Machine: “Development,” Depoliticization, and Bureaucratic Power in Lesotho. Minneapolis: University of Minnesota Press, 1994.

Gebre A., Getachew, D. \& McCartney, M. Stakeholder analysis of the Koga Irrigation and Watershed Management Project, Report for the International Water Management Institute, 2007.

Geertz, C. The Interpretation of Cultures, New York: Basic Books, 1973.

Gupta, A. 'Blurred boundaries - the discourse of corruption, the culture of politics, and the imagined state’. American Ethnologist 22, no. 2 (1995): 375-402.

Gupta, A. Postcolonial developments: agriculture in the making of modern India, Durham: Duke University Press, 1998.

Hall, S. “Cultural identity and cinematic representation”. Framework, 36 (1989): 68-81. 
Hansen, T. B. \& Stepputat, F. eds. States of imagination: ethnographic explorations of the postcolonial state, Durham N.C.: Duke University Press, 2001.

Hickey, S. \& Mohan, G. "Relocating participation within a radical politics of development”. Development and change 36, 2 (2005): 237-262. 37.

Lefort, R. "Powers-Mengist—and Peasants in Rural Ethiopia: The May 2005 Elections". Journal of Modern African Studies, 45, 2 (2007): 253 - 273.

Lefort, R. 'Free market economy, 'developmental state' and party-state hegemony in Ethiopia: the case of the 'model farmers'”. Journal of Modern African Studies, 50, 4 (2012): 681-706.

Lund, C. 2006. “Twilight Institutions. Public Authority and Local Politics in Africa”. Development and change, 37, 4 (2006): 686-705.

Long, N. Development Sociology: Actor Perspectives, London: Routledge, 2001.

Mayrl, D. \& Quinn, S. 2016. "Defining the state from within: Boundaries, schemas, and associational policymaking”. Sociological Theory, 34 (2016): 1-26.

Migdal, J. S. State in society: studying how states and societies transform and constitute one another, Cambridge; New York: Cambridge University Press, 2001.

Ministry of Water Resources (MoWR) [MoWIE]. Koga irrigation: development and social constraints, Addis Ababa: MoWR [MoWIE], 2005.

Mott MacDonald (MMD). Koga Irrigation Project: Implementation and Operation - Issues of Concern, Addis Ababa, and December 2005a.

Mott MacDonald (MMD). Koga Irrigation Project: Water User Associations, Working Paper 12. Addis Ababa, December 2005b.

Mitchell, T. “Society, Economy, and the State Effect”. In State/culture: state formation after the cultural turn, edited by G. Steinmetz, 76-97. Ithaca and London: Cornell University Press, 1999. 
Planel, S. “A view of a bureaucratic developmental state: local governance and agricultural extension in rural Ethiopia”. Journal of Eastern African Studies, 8, 3 (2014): 420-437.

Scott, J. Weapons of the Weak: Everyday Forms of Peasant Resistance. New Haven: Yale University Press, 1985.

Scott, J. Seeing like a State: how certain schemes to improve the human condition have failed, New Haven: Yale University Press, 1998.

Smit, H., Rahel M., Ahlers R., van der Zaag, P. “The Political Morphology of DrainageHow Gully Formation Links to State Formation in the Choke Mountains of Ethiopia”. World Development, 98, (2007) 231-244.

Vaughan, S. and K. Tronvoll. The Culture of Power in Contemporary Ethiopian Political Life. Stockholm: Sida, No, 10, 2003.

Vaughan, S. Revolutionary Democratic State Building: Party, State, and People in EPRDF's Ethiopia. Journal of Eastern African Studies, 5, 4 (2011): 579-95.

Williamson, V. So near and yet so far: Values and mental models along the aid chain in. Ethiopia. Journal of International Development, 23, 6 (2011): 823-835. 